\title{
Proposal of experimental device for the continuous accumulation of primary energy in natural gas hydrates
}

\author{
Ján Siažik ${ }^{1, *}$, Milan Malcho ${ }^{1}$ and Richard Lenhard ${ }^{1}$ \\ ${ }^{1}$ University of Žilina, Faculty of Mechanical Engineering, Department of Power Engeneering, Univerzitna 1, 01026 Žilina, Slovakia
}

\begin{abstract}
Hydrates of the natural gas in the lithosphere are a very important potential source of energy that will be probably used in the coming decades. It seems as promising accumulation of the standard gas to form hydrates synthetically, stored, and disengage him when is peak demand. Storage of natural gas or biomethane in hydrates is advantageous not only in terms of storage capacity, but also from the aspect of safety storage hydrates. The gas stored in such form may occurs at relatively high temperatures and low pressures in comparison to other Technologies of gas- storage. In one cubic meter of hydrate can be stored up to $150 \mathrm{~m}^{3}$ of natural gas, depending on the conditions of thermobaric hydrate generation. This article discusses the design of the facility for the continuous generation of hydrates of natural gas measurement methodology and optimal conditions for their generation.
\end{abstract}

\section{Introduction}

Hydrates have been for decades treated as a potential energy source especially for countries with limited access to conventional hydrocarbon fuels or for countries with strategic interest for the creation of alternative supplies of natural gas. Hydrate is generally a substance containing water and hydrocarbons (or other gas). The storage of natural gas hydrates methane in particular, is preferable particularly in view of storage capacity, but also from the aspect of safety storage of gas, due to higher temperatures and lower pressures in comparison to other storage technologies. Gas hydrate is a solid state, which compose from about $85 \%$ water and $15 \%$ gas clathrate bound in the lattice. The hydrates also involve some uncertainty due to the ongoing research and their use as potential sources of revenue. Gas hydrate can be a great source of energy that will be included in the consideration as supply of natural gas for next decades. It is estimated that $99 \%$ of the world reserves of gas hydrates are found in marine sediments at appropriate temperature and pressure conditions prevailing in the upper meters at sea bed, and in the sediments at depths of up to $300 \mathrm{~m}$ and $4000 \mathrm{~m}$. Hydrates can also occur on the mainland, but only in areas of permafrost, thus the long-term frozen surface areas with year-round temperatures below $0{ }^{\circ} \mathrm{C}$. Saving energy in suitable form for safe gas storage and its subsequent release consists of many challenges. At the moment, we have emphasized the overall efficiency of these processes, the light use efficiency, increasing the efficiency and safety of the energy storage. The aim of the use of methane hydrates in practice could be, for example ensuring coverage of peaks in the cogeneration of electricity and heat with gas released from hydrates.
In our prototype equipment for the hydrate generation the gas hydrate will be prepared from water and gas as a solid hydrate. The work will be using natural gas as gas hydrates forming gas and energy requirements of hydrates. It is further proposed a high-pressure circuit diagram of an experimental apparatus for production of gas hydrates with a design pressure of $25 \mathrm{MPa}$, which would maintain the necessary state quantities to determine suitable parameters for the storage of gas hydrate structures. The device, which will be implemented in the continuation of this work should also serve to identify specific energy consumption for the formation of hydrates.

\section{Natural gas as gas forming hydrates}

A number of different gases can produce clathrates of binding with a molecule of water. In the article the focus will be on creating the most widely used gas hydrate energy carriers - natural gas.

\subsection{Natural gas}

Natural gas from the physical point of view is a combination of gas, the main component is methane. Natural gas is often found together with oil or coal. Natural gas is a colourless, in itself odourless, flammable gas. Belongs to a group of heating gas and is used for heating, cooking, water heating, also in heating plants, cogeneration units and transport (such as motor vehicles). It can be used also in other forms. One form of a CNG (Compressed Natural Gas), that is, compressed natural gas at a pressure of $20 \mathrm{MPa}$. The second form of the LNG (Liquefied Natural Gas), liquefied natural gas

* Corresponding author: jan.siazik@,fstroj.uniza.sk 
at $-162{ }^{\circ} \mathrm{C}$. It consists primarily of methane and higher hydrocarbons with a small admixture of inert gases. Natural gas is not toxic, rarefied and lighter than air. [1]

\subsection{Hydrates of natural gas}

Gas hydrates are ice-like crystalline solids that form from mixtures of water and light natural gases such as methane, carbon dioxide, ethane, propane and butane. Methane was the dominant component among other hydrocarbon gases in the sediments. Gas hydrates, potentially one of the most important energy resources for the future. Methane gas hydrates are increasingly considered a potential energy resource. In the fig. 1 is shown a burning of methane hydrate sample.

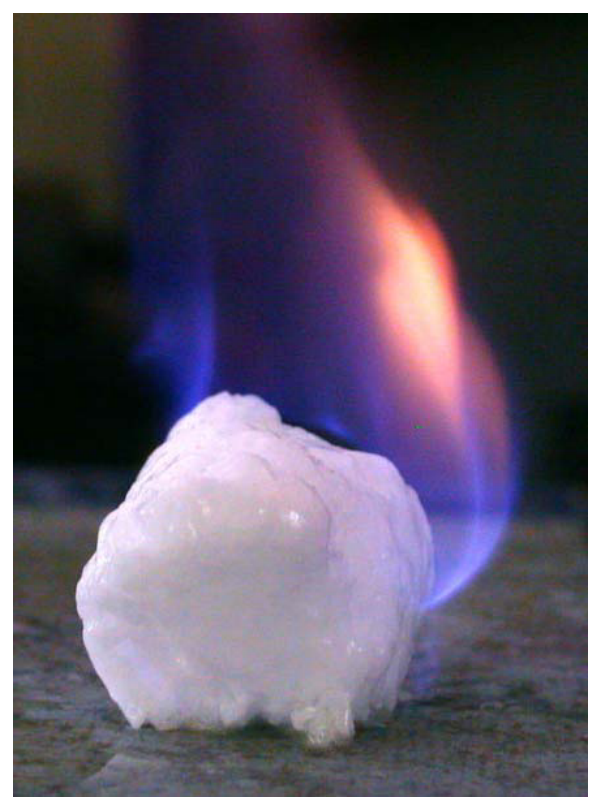

Fig. 1. Burning of methane hydrate sample

Enormous reserves of hydrates can be found under continental shelves and on land under permafrost. Gas hydrate or clathrate consists of three general structure types. Depending on the size of the guest molecule, natural gas hydrates can consist of any combination of three crystal structures: (1) Structure I or sI, (2) Structure II or sII and (3) Structure H or sH. When pure liquid water freezes it crystallizes with hexagonal symmetry, but when it freezes as a hydrocarbon hydrate it does so with cubic symmetry for sI and sII, reverting to hexagonal symmetry for $\mathrm{sH}$. Methane hydrates are widespread in sea sediments in depths of hundreds meters below the sea floor along the outer continental margins and are also found in Arctic permafrost. Some deposits are close to the ocean floor and at water depths as shallow as $150 \mathrm{~m}$, although at low latitudes they are generally only found below $500 \mathrm{~m}$. The deposits can be 300-600 m thick and cover large horizontal areas. Hydrates may affect climate because when warmed or depressurized, they decompose and dissociate into water and methane gas, which is one of the greenhouse gases that contributes to global warming. Methane hydrates hold the danger of natural hazards associated with sea floor stability, release of methane to ocean and atmosphere and gas hydrates disturbed during drilling pose are a safety problem. [2]

\subsection{Formation of natural gas hydrates}

Hydrates gas forms water ice containing a large amount of methane clathrate bound in the form - in the cavities of the crystal lattice. This is a solid ice-like compound whose existence on earth has been known since the 50s of the 20th century. Cubic meter of solid hydrate is containing an average of about $164 \mathrm{~m}^{3}$ of methane in the gaseous form. Hydrate density varies around $900 \mathrm{~kg} . \mathrm{m}^{-3}$ at room temperature, the pressure is unstable. Their formation can be partially attributed to the thermal decomposition of organic matter, mostly oil. [3] The stability of natural gas hydrates is relate to the structure these substances and interactions, that underway of certain physical conditions. Conditions of hydrates are characterized by:

- the presence of water and the concentration that is necessary for the formation of the hydrate lattice, the appropriateness of using the geometry of the existence of the water molecules and the hydrogen bonds to form a grid,

- presence, kind and concentration of the guest molecules,

- the pressure and temperature of the medium in which hydrates will occur. [1]

Hydrates are thus crystalline solid generated by the contact of liquid water with the hygroscopic small gas molecules such as methane, ethane, hydrogen sulfide or carbon dioxide under specific pressure and temperature. The initial conditions for hydrate formation is the presence of water and the existence of ties necessary for creating a grid that fills the guest molecule. This creates basic cell. The sequence of the gas hydrate is in fig. 2 .

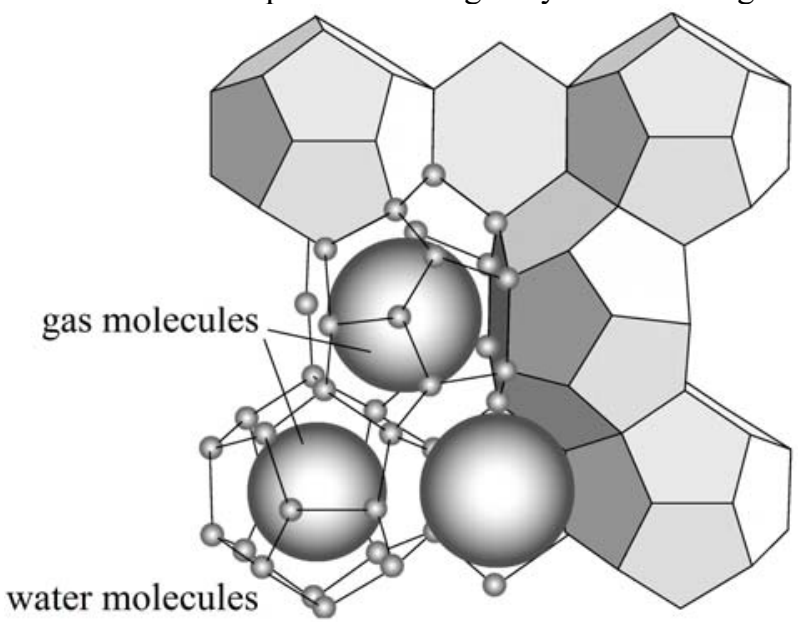

Fig. 2. Typical structure of gas hydrate

In relation to the conditions of formation and growth is known that hydrate is produced at high pressure and low temperature. Completion of the grid requires the presence of molecules of gas $\left(\mathrm{CH}_{4}, \mathrm{C}_{2} \mathrm{H}_{6} \ldots\right)$ for creating a water grid. [4]

The creation of hydrates is affected further by: - turbulence - at high flow rates is the formation of 
hydrates is supported in places where a high flow rate is present (gas flow control at points). Increasing the velocity of the gas is due to the reduced flow through the valve space. On reducing the temperature due to the Joule-Thomson effect, - at stirring gas - gas hydrates can be formed due to mixing of gases in pipes or warehousing

- site creation - it's a volume where it is supported by a phase transition that occurs in the formation of the solid phase (from the liquid phase). Formation of hydrates may occur with errors in pipe welds, bends, valves, etc. Also, where are deposits, contaminants, such as mud and sand. [5]

The hydrates may form hydrogen bonds along the edges of the grids accordingly, to the impact energy of hydrogen bonds as in the ice. Water molecules in clathrates have fewer configuration degrees of freedom as they have in the case of ice. Grid ice is stable and does not contain a guest molecule. In the case of an empty grid unstable hydrates to the structure have to be stabilized by van der Walls interactions to the presence of the molecule within the grid. [6]

Depending on the type of gas composition - by the host in the hydrate- the density of the hydrate is from $800-1200 \mathrm{~kg} \cdot \mathrm{m}^{-3}$.

Hydrates features:

- $1 \mathrm{~m}^{3}$ of water may be bound $207 \mathrm{~m}^{3}$ of methane in the form of a solid hydrate with volume of $1.26 \mathrm{~m}^{3}$, whereas without the gas comprises about $1 \mathrm{~m}^{3}$ of water freezing ice into 1.09 cubic meters,

- the unit volume of methane hydrate at a pressure of 26 bar and a temperature of $0{ }^{\circ} \mathrm{C}$ is containing 164 units of gas,

- the hydrates is by $80 \%$ of the volume filled with water and $20 \%$ gas. [7]

Gas hydrates form three crystal structures (shown in fig. 3) cubic structure I, structure II, cubic and hexagonal structure $\mathrm{H}$. The structure of $\mathrm{I}$ is the simplest and is composed of 46 water molecules. It consists of two small spherical cavities with twelve pentagonal faces $\left(5^{12}\right)$, followed by six large cavities with two hexagonal faces and twelve pentagonal faces $\left(5^{12} 6^{2}\right)$. It is occupied by methane, $\mathrm{CO}_{2}$ and hydrogen sulfide in small cavities. For large cavities it is occupied by ethane. The structure of II is composed of 136 water molecules. It consists of sixteen small cavities with twelve pentagonal faces $\left(5^{12}\right)$, followed by eight large cavities with twelve pentagonal and hexagonal four walls $\left(5^{12} 6^{4}\right)$. All are located in a spherical model. The structure is occupied by nitrogen which includes large and small cavities, propane and isobutane. These molecules make up only a cavity. The structure $\mathrm{H}$ is formed by 34 water molecules. It consists of small chambers, in some cases, large chamber. The structure $\mathrm{H}$ hydrates produces a 2 methylbutane, 2,2-dimethylbutane, methylcyclohexane.

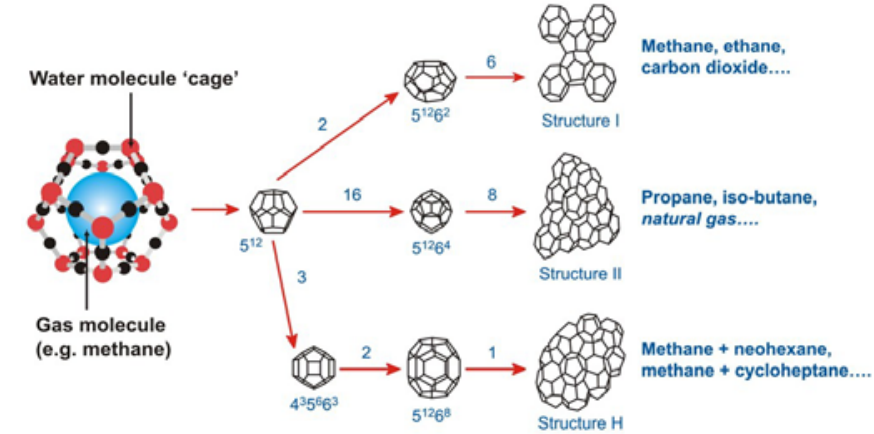

Fig. 3. The gas hydrate structures

\subsection{The occurrence of natural gas hydrates}

Gas hydrates are formed in a medium at high pressure and low temperature in the presence of sufficient water, and gas. On the following figure 4 is a phase diagram of the formation of methane hydrate.

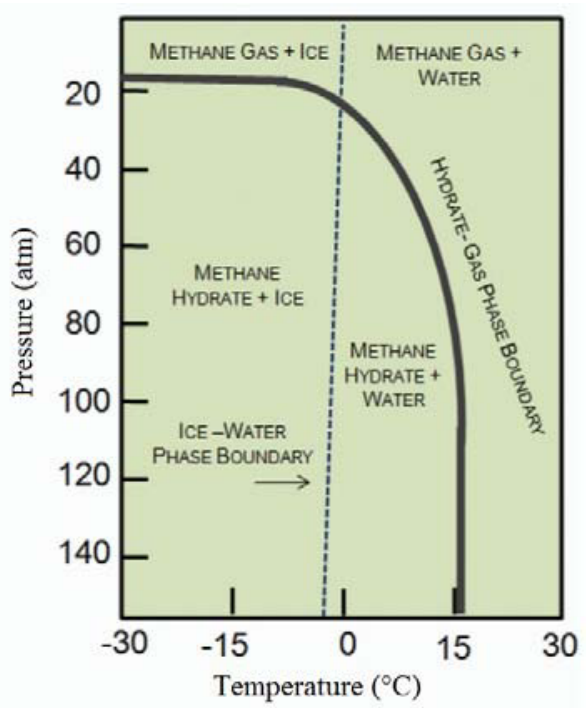

Fig. 4. Phase diagram for methane hydrate formation.

The requirements of hydrate formation restrict the occurrence of natural gas hydrates to two types of geologic locations:

- under permafrost in the polar continental shelves

- in sediment beneath the ocean floor.

\section{Proposal experimental facility}

Phenomenon of typical power consumption is for example uneven consumption of natural gas and biomethane in cogeneration units at peak load. Just energy-efficient accumulate of natural gas hydrates in a controlled manner to release the gas could be as a source of primary energy and thus could cover the peak load. High-pressure experimental apparatus for production of gas hydrates is proposed, which would maintain the necessary state variables for the determination of appropriate parameters of the accumulation of gas in the hydrate structure with a design pressure of 250 bar. Under the scheme of fig. 6 is made a device with which it will be possible to determine the specific energy 
consumption for the formation of hydrates. Identifying the parts of the scheme is in Tab. 9.

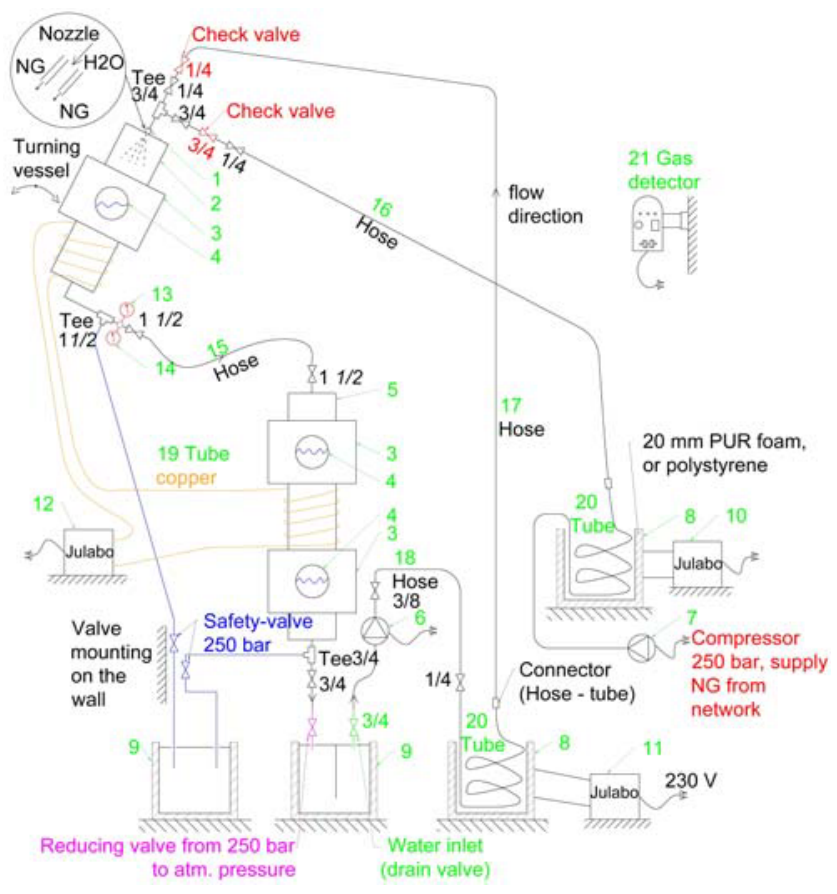

Fig. 6. Schematic diagram of experimental equipment

Experimental facility is under development and procurement of components and it's possible to start measurements with pressure under 100 bar. Pump 6 will suck distilled water which is compressed to a pressure of 100 bar, and which will pass through stainless steel tube 19. The container 8 will be connected to 11 Julabo circulation thermostat with pum which will ensure cooling water in the tube by pressing the set temperature. The water pressure of 100 bar will continue to the hose 17 toward the nozzle. Second, the gas compressor 7, squeeze the gas to a pressure of 100 bar, which will flow into the hose 20 . The stainless steel tubing 20 is wound into a coil and positioned in a container 8 which is connected to Julabo 10. This is conducted to provide the cooling of the gas after its compression to the desired temperature. The compressed gas is mixed with the compressed water and together they enter the nozzle 1. The nozzle is designed to atomize the mixture of water and compressed gas into small particles, which will make possible a better binding to the natural gas-hydrate form of molecular bonds. The mixture of water and gas should flow from the first container 2 through a hose 15 into a high pressure vessel 5 after its fulfilment. After filling of the container with a mixture of high-pressure gas and water visible area can be observed through the sapphire viewing windows 4 , with sealed shut-off valve $3 / 4$ (located under high pressure vessel 5). From that moment will run hydrate formation germs, and will be measured in time for hydrate formation. After nucleated hydrates, the entire device can be depressurized and remove them through the flange and further investigate under the microscope. The electronic manometer can be connected to the measurement panel. The entire facility are 4 sapphire visors ( 2 pieces per container 2 and 2 per container 5), the other holes are covered, with blind flanges. Other undescribed valves in schematic diagram are shut off valves with the right pressure to 250 bar. Description of the proposed valve is in Tab. 10. In the laboratory will be located gas detector 21 , to monitor the environment. Accidental increase of the gas concentration in the air will warn the audio response sensor.

Table 1. Position on the diagram of experimental equipment

\begin{tabular}{|c|c|c|}
\hline Poz. & Title & Model/type or performance \\
\hline 1 & Nozzle & $\begin{array}{l}\text { Spray angle } 51^{\circ} \text { and } 155^{\circ}, \\
\text { external thread } 1 / 4^{\prime \prime}\end{array}$ \\
\hline 2 & $\begin{array}{l}\text { High pressure } \\
\text { vessel }\end{array}$ & $\begin{array}{c}\phi 175 / 146,9 \mathrm{~mm}, \mathrm{~m}=42 \mathrm{~kg}, 5.71 \\
\mathrm{G} 1^{1 / 2} 2^{\prime \prime}, \mathrm{l}=600 \mathrm{~mm}, \mathrm{p}=250 \mathrm{bar}\end{array}$ \\
\hline 3 & $\begin{array}{l}\text { Flange on the } \\
\text { container }\end{array}$ & Steel flange $255 \times 255 \mathrm{~mm}$ \\
\hline 4 & $\begin{array}{l}\text { Sapphire sight } \\
\text { glass }\end{array}$ & $\begin{array}{c}\phi 50 \mathrm{~mm}+0 /-0.1 \mathrm{~mm} \\
\text { thickness } 20.0 \mathrm{~mm} \pm 0.1 \mathrm{~mm}\end{array}$ \\
\hline 5 & $\begin{array}{l}\text { High pressure } \\
\text { vessel }\end{array}$ & $\begin{array}{l}\phi 175 / 146.9 \mathrm{~mm}, \mathrm{~m}=73 \mathrm{~kg}, 151 \\
\mathrm{G} 1^{1} \mathrm{2}^{\prime \prime}, \mathrm{l}=1159 \mathrm{~mm}, \mathrm{p}=250 \mathrm{bar}\end{array}$ \\
\hline 6 & Plunger pumps & $\begin{array}{c}\mathrm{p}_{\max }=450 \mathrm{bar}, \\
\mathrm{T}_{\max }=70^{\circ} \mathrm{C}, \mathrm{Q}=5,11 \mathrm{~min}^{-1}\end{array}$ \\
\hline 7 & $\begin{array}{l}\text { Natural gas } \\
\text { compressor }\end{array}$ & $\mathrm{CNG}, 3 \mathrm{~kW}, 400 \mathrm{~V}, 50 \mathrm{~Hz}$ \\
\hline 8 & $\begin{array}{l}\text { Container } \\
\text { refrigeration }\end{array}$ & Material plastic \\
\hline 9 & $\begin{array}{l}\text { Container } \\
\text { discharge }\end{array}$ & Material plastic \\
\hline 10 & $\begin{array}{l}\text { JULABO FL } \\
2503\end{array}$ & $\begin{array}{c}\mathrm{p}_{\max }=27 \text { bar, refrigerant } \\
\mathrm{R} 404 \mathrm{a}, 230 \mathrm{~V}, 50 \mathrm{~Hz}\end{array}$ \\
\hline 11 & $\begin{array}{l}\text { JULABO F 32, } \\
\text { JULABO MA }\end{array}$ & $\begin{array}{c}\mathrm{p}_{\max }=27 \text { bar, refrigerant } \\
\mathrm{R} 134 \mathrm{a}, 230 \mathrm{~V}, 50 \mathrm{~Hz}\end{array}$ \\
\hline 12 & $\begin{array}{l}\text { JULABO FP 40, } \\
\text { JULABO HE }\end{array}$ & $\begin{array}{c}\mathrm{p}_{\max }=25 \text { bar, refrigerant } \\
\mathrm{R} 404 \mathrm{a}, 230 \mathrm{~V}, 50 \mathrm{~Hz}\end{array}$ \\
\hline 13 & $\begin{array}{l}\text { Pressure gauge } \\
\text { pointer }\end{array}$ & $\begin{array}{c}\text { PTL GC0015, STN EN } 837 \\
40 \mathrm{MPa}\end{array}$ \\
\hline 14 & $\begin{array}{l}\text { Electronic } \\
\text { manometer }\end{array}$ & 0-300 bar, 4-20 mA \\
\hline 15 & $\begin{array}{l}\text { Hose for natural } \\
\text { gas }\end{array}$ & $\begin{array}{l}\text { WP } 385 \text { bar, SAE 100, length } \\
2 \mathrm{~m}, \text { DN } 34^{\prime \prime} \text {, DIN EN } 856 \text { 4SP }\end{array}$ \\
\hline 16 & $\begin{array}{l}\text { Hose for natural } \\
\text { gas }\end{array}$ & $\begin{array}{l}\text { WP } 400 \text { bar, 1Q16, length 3m, } \\
\text { EN } 853 \text { 2SN6 }\end{array}$ \\
\hline $\begin{array}{l}17 \\
18\end{array}$ & Hose & $\begin{array}{l}\text { WP } 400 \text { bar, DN 1/8", EN-853 } \\
\text { 2SN } 17(1=3 \mathrm{~m}), 18(\mathrm{l}=4 \mathrm{~m})\end{array}$ \\
\hline 19 & Seamless tube & $\begin{array}{c}\text { cupper D/d/1 } \\
\phi 10 / \phi 8 \mathrm{~mm} / 50 \mathrm{~m}, \mathrm{STN} \text { EN } 1057\end{array}$ \\
\hline 20 & Seamless tube & $\begin{array}{c}\text { Stainless steel D/d/1 } \\
\phi 10 / \phi 7 \mathrm{~mm} / 30 \mathrm{~m} ; \text { do } 30 \mathrm{MPa} \\
\text { DIN } 17458\end{array}$ \\
\hline 21 & Gas detector & $\begin{array}{l}\text { Detection LPG, NG, coal-gas, } \\
100-240 \mathrm{~V}, 50 / 60 \mathrm{~Hz} \text {, volume } \\
>85 \mathrm{~dB} \text {, range }-10^{\circ} \mathrm{C} \text { to } 50^{\circ} \mathrm{C}\end{array}$ \\
\hline
\end{tabular}

\subsection{Energy intensity of hydrate creation}

Energy consumption can be generally expressed through coefficient EROEI which reflects energy returned on energy invested. If the ratio is equal to or less than 1 , source of energy becomes as energy sink and may not 
be already used as the primary power source. The following are the equations needed to estimate energy intensity of creation of methane hydrate. The following are mentioned nomenclature and method of calculation. Volume flow of natural gas is $\dot{V}_{N G}=1.388 \times 10^{-3} \mathrm{~m}^{3} \cdot \mathrm{s}^{-1}$, volume flow water has been established $\dot{V}_{W}=8.325 \times 10^{-6} \mathrm{~m}^{3} \cdot \mathrm{s}^{-1}$, operating water pressure $\Delta p_{W}=4.9 \times 10^{6} \mathrm{~Pa}$, pump efficiency $\eta_{\mathrm{P}}=0.6$, primary energy factor $f_{\mathrm{e}}=2.57$. Physical input power consumption of pump $N_{P}$ [W] is calculated by using eq. (1) and substituting into eq. (2) is calculated primary energy of pump $E_{P P}[\mathrm{~W}]$.

$$
\begin{aligned}
& N_{P}=\frac{\Delta p_{W} \cdot \dot{V}_{W}}{\eta_{P}} \\
& E_{P P}=N_{P} \cdot f_{e}
\end{aligned}
$$

It is also known inlet pressure $\mathrm{p}_{1}=1 \times 10^{5} \mathrm{~Pa}$, outlet pressure $\mathrm{p}_{2}=1 \times 10^{7} \mathrm{~Pa}$, polytropic exponent $\mathrm{n}=1.2$, compressor efficiency $\eta_{\mathrm{C}}=0.6$. Compression power of compressor $\mathrm{A}_{\mathrm{TC}}[\mathrm{W}]$ is given by eq. (3) and substituting into the eq. (4) is obtain input power consumption of compressor $\mathrm{P}_{\mathrm{C}}[\mathrm{W}]$. Primary energy of compression of natural gas $E_{P N G}[\mathrm{~W}]$ is given by eq. (5).

$$
\begin{gathered}
A_{T C}=\frac{n}{n-1} \cdot p_{1} \cdot \dot{V}_{1} \cdot\left[\left(\frac{p_{2}}{p_{1}}\right)^{\frac{n-1}{n}}-1\right] \\
P_{C}=\frac{A_{T C}}{\eta_{C}} \\
E_{P N G}=P_{C} \cdot f_{e}
\end{gathered}
$$

Another well-known quantities are density of natural gas $\rho_{\mathrm{NG}}=0.72 \mathrm{~kg} \cdot \mathrm{m}^{-3}$, water density $\rho_{\mathrm{W}}=1000 \mathrm{~kg} \cdot \mathrm{m}^{-3}$, specific heat capacity of natural gas $\mathrm{c}_{\mathrm{NG}}=1609$ $\mathrm{J} \cdot \mathrm{m}^{-3} \cdot \mathrm{K}^{-1}$, specific heat capacity of water $\mathrm{c}_{\mathrm{W}}=4187$ $\mathrm{J} . \mathrm{kg}^{-1} \cdot \mathrm{K}^{-1}$, cooling factor $\mathrm{f}_{\mathrm{R}}=3.5$, temperature difference $\Delta \mathrm{t}=30^{\circ} \mathrm{C}$, it includes the ambient temperature $10^{\circ} \mathrm{C}$. Energy for cooling the natural gas $\dot{Q}_{N G}[\mathrm{~W}]$ is given by the equation (6), input power consumption of cooling natural gas $\mathrm{P}_{\mathrm{NG}}[\mathrm{W}]$ is given by eq. (7). Energy for cooling the water $\dot{Q}_{W}$ [W] is shown by eq. (8) and input power consumption of cooling water $\mathrm{P}_{\mathrm{W}}[\mathrm{W}]$ is calculated by eq. (9).

$$
\begin{gathered}
\dot{Q}_{N G}=\rho_{N G} \cdot \dot{V}_{N G} \cdot c_{N G} \cdot \Delta t \\
P_{N G}=\frac{\dot{Q}_{N G}}{f_{R}} \cdot f_{e} \\
\dot{Q}_{W}=\rho_{W} \cdot \dot{V}_{W} \cdot c_{W} \cdot \Delta t
\end{gathered}
$$

$$
P_{W}=\frac{\dot{Q}_{W}}{f_{R}} \cdot f_{e}
$$

Calorific value of natural gas is $\mathrm{Q}_{\mathrm{CV}}=34 \times 10^{6} \mathrm{~J} . \mathrm{m}^{-3}$, primary usable energy $\mathrm{E}_{\mathrm{PU}}[\mathrm{W}]$ is given by eq. (10). Relationship for calculating the coefficient EROEI generally is shown eq. (11). Equations (2), (5), (7), (9), (10) were put into adjusted equation for calculating EROEI (12) under our case for methane hydrate formation.

$$
\begin{gathered}
E_{P U}=\dot{V}_{N G} \cdot Q_{C V} \\
E R O E I=\frac{\text { Energy returned }}{\text { Energy invested }} \\
E R O E I=\frac{E_{\mathrm{PU}}}{E_{\mathrm{PP}}+E_{P N G}+P_{N G}+P_{W}}
\end{gathered}
$$

Estimated value coefficient given by eq. (12) has a coefficient value of EROEI $=10.6$ after rounding number. This value is favorable however, actual values of coefficient will be streamed after evaluaiton of the measurement. The calculation was framework with limited data and energy inputs are related to primary energy. The following are mentioned studies, which can be seen as moving EROEI value depending on the case. Study by [8] where was created model the heating of submarine methane hydrate deposits located at depths between 1000 and 1500 meters, when the heating is supplied by hot water flowing through a horizontal pipe located inside the reservoir. EROEI factors begin at 28 as the water starts flowing, and reduce to a value of 2.8 after fifty years of production, but it is quite a different case. Another study by [9] says that for crude oil, a very wide range of EROEI values apply, depending inter alia on the depth of the well and on whether the well is on- or offshore. In these early years of the 21 st century a range of 3-10 is often expressed. Next study by [10] says about fuel sources and regions oil and gas production for Canada EROEI value of 15 in year 2010.

\section{Conclusion}

Interesting way how to accumulate energy of natural gas is using hydrates of natural gas. According to previous studies, it appears to be advantageous to store natural gas into hydrates and in terms of operational or relatively safe conditions compared to $\mathrm{CNG}$ - where is required higher pressures or LNG - where is required lower temperatures. Both of these options are energy intensive. Estimated factor EROEI for the formation of methane hydrate under laboratory conditions was calculated to value of 10.6. If the EROEI that we determined on this paper had been less than number 1 , production methane hydrate would be useless.

Work on article has been financially supported by the project VEGA-1/0718 / 15th Accumulation of high potential energy through the process of generating hydrates of natural gas and biomethane. 


\section{References}

1. V. Foltin, Natural Gas Hydrates - Challenge and Opportunity (2013)

2. A. Demirbas, Energy Conversion and Management, 51, 7, (2010)

3. S. Depowski, Surowce energetyczne, 10 (1998)

4. A. Kvenvolden, Gas hydrates as a potential energy resource, 1570 (1993)

5. J. Carroll, Natural gas hydrates: A guide for engineer, Burlington (2003)

6. F. Franks, Water a Matrix of Life, 2nd edition, (2000)

7. F. Makogon, Natural Gas Hydrates - A promising Source of Energy, 2,1 (2010)

8. B. Sunden, C. A. Brebbia, D. Poljak, Advanced Computational Methods and Experiments in Heat Transfer XII, (2012)

9. C. J. Jones, IJMEE, 36, 6 (2008)

10. Ch. A. S. Hall, EP, 64, 12 (2014)

11. M. Holubčík, J. Jandačka, Š. Papučík, P. Pilát, Manufacturing Technology, 15 (2015)

12. J. Jandačka et al., Emisné zataženie životného prostredia, 1 (2014)

13. Š. Rezničák, M. Malcho, J. Siažik, Time of formation of methane hydrates, AeaNMiFMaE 2016 (2016)

14. M. Novomestský, Š. Papučík, J. Siažik, Heat performance of heat pipe thermosyphon, AeaNMiFMaE 2016 (2016)

15. J. Siažik, M. Malcho, Energy transformation in industry 2015 (2015)

16. P. Durčanský, Š. Papučík, J. Jandačka, M. Holubčík, R. Nosek, Scientific World Journal, 55, 138254 (2014) 